\title{
ハンドル形電動車いすの自動減速による 搭乗者への効果に関する研究
}

\author{
猪井＼cjkstart博登1 ・橋本 真彌 2 栗山 龍起 3 ・岡田 和也4 \\ 1正会員 大阪大学助教 大学院工学研究科地球総合工学専攻（干565-0871 大阪府吹田市山田丘2-1） \\ E-mail: inoi@civil.eng.osaka-u.ac.jp \\ 2学生非会員 大阪大学 大学院工学研究科地球総合工学専攻（干565-0871 大阪府吹田市山田丘2-1） \\ E-mail: hashimoto.shinya@civil.eng.osaka-u.ac.jp
}

3非会員 IDEC株式会社 規格安全ソリューションセンター（†532-8550 大阪市淀川区西宮原1-7-31）

E-mail: kuriyat@idec.co.jp

4非会員ＩDEC株式会社＼cjkstart規格安全ソリューションセンター（†532-8550 大阪市淀川区西宮原1-7-31）

E-mail: kokada@idec.co.jp

近年，ハンドル形電動車い寸利用者による単独事故が増えてきている．そこで本研究では新たな対策と してハンドル形電動車いすを自動減速をさせることによる搭乗者の運転を支援システムを提案する。この システムは，レーザースキャナによって実現される，ハンドル形電動車いすの運転経験がない者を対象に 行った実験の結果, 実験コースにおいて自動減速をおこなうことで搭乗者の操作性を向上した. また, 特 にハンドル形電動車いすの運転を難しいと思う人ほど効果があった.

Key Words : barrier free, mobility, safety assessment, accident countermeasures

\section{1. 序章}

(1) ハンドル形電動車いすの普及と問題点

近年，高齢者や身体障害者のように身体的ハンディを 理由に移動を自由に行えない人が多く存在する. 65 歳 以上の高齢人口は総人口の $23.1 \%$ 占めており（2011 年 10 月 1 日現在），40 年後には高齢化率が $40 \%$ に達寸る と見通されている1). 高齢化が進むわが国では，身体的 な理由により移動に困難を抱える人たちが今後ますます 増えていくと予想される，そのため，このように移動に 困難を抱える人たちのための移動手段が必要となる.

近年では移動手段の一つとしてハンドル形電動車い寸 が利用されている. ハンドル形電動車い寸は，操作が簡 単で気軽に移動できるといったことや，一定の条件を満 たせばレンタル費用が介護保険で補助されることなどか ら需要が伸び，使用者の数は年々増加している2). 具体 的な使用者数は把握されていないが，電動車い寸安全普 及協会2)によると，2011 年の単年のハンドル形電動車い すの出荷台数は 13,670 台に上り, 累計の出荷台数は 447,310 台に上る. 同じく, ジョイステック型電動車い すの 2011 年の単年出荷台数が 6,080 台, 2011 年までの
累計出荷台数が 145,702 台であることからも，ハンドル 形電動車い寸の利用者が増えていることがわかる．しか しながら利用が増える一方で，ハンドル形電動車い寸の 利用に関して問題も出てきている.

具体的には，ハンドル形電動車い寸の利用が増えるに したがって，関連する事故も増えてきている．製品評価 技術基盤機構引によると，電動車いすの事故情報は 1985 年 5 月から 2008 年 1 月末までに報告された事故情報は 96 件であり, 2002 年から増加傾向にあり, 2003 年以降 は年間 11 件以上の事故情報を受け付けているとしてい る. なお，ここで言う単独事故とは，製品評価技術基盤 機構で収集する事故情報であり, 製品事故であって（自 損事故を含む。），交通事故は含まない。このうち，死 亡事故が 23 件, 重傷事故が 5 件で死亡・重傷事故が全 体の約 30\%を占めている. また，原因がわかっている 死亡・重傷事故のうち約半数が使用者の誤使用または不 注意が原因で起こった事故であることがわかっている.

また，近年では利用者の要望により公共交通機関や公 共施設内でハンドル形電動車い寸を利用できるようにな る4)など，屋内で使用する機会が増えてきている．しか しながら，屋内は物理的制約がある所が多いうえ，現在 
の建物や公共交通機関の整備基準にハンドル形電動車い すは想定されていない5ため，ハンドル形電動車いすで 走行するには狭い場所もあるなど移動に支障が出ること が想定される4).

ハンドル形電動車いす利用者が安全かつ自由に移動す るためには，ハンドル形電動車いすに対応した整備が求 められる一方で，事故に対する対策や狭い空間でも走行 できるような対策が早急に求められる.

\section{（2）現在の対策と問題点}

現在行われている事故対策としては，2009 年におこ なわれた，JS T 9208 の制定があげられる.この JIS の制 定により，ハンドル形電動車い寸独自の基準が制定され， 安定性能の増加, リスクマネジメントによる設計の追加 などが規定された。この結果, 転倒しにくくなる，故障 しにくくなるなど, 製品に起因する事故は減っていくと 予測される。しかしながら一方で，今回の JIS の改正は 車体に関する基準がメインで，搭乗者の操作ミスや判断 ミスによる事故を防ぐことは期待できない．現在ある操 作ミスを防ぐ対策としては握り込み緊急停止機能のなど があるものの，現在ある機能があっても事故が起こって いることを考えると，現状の対策だけではまだ不十分で ある. なお, 握り込み緊急停止機能とは, 事故や緊急の 際にアクセルを握り込んでしまうことが多いことから， 握り込みが行われた際にブレーキがかかる仕組みのこと である，また，屋内の移動に対する対策は，従来のハン ドル形電動車いすより回転性能が向上した屋内向けの改 良型ハンドル形電動車いすが販売されている。しかしな がら小回り性と旋回安定性はトレードオフの関係にあり， 回転性能が良くなると安定性が悪くなってしまい，転倒 などの事故につながる可能性もある．安定を維持しつつ 狭い空間でも走行しやすくするには，現行でおこなわれ ている対策では不十分であり，新たな対策が求められる。 現行の対策では機械側，走行環境側からの対策はおこな われているが，搭乗者側からの対策が行われていないの が現状である.よって新たな対策が必要である.

\section{(3) 研究の目的}

本研究では新たな対策として，ハンドル形電動車いす を自動減速させることにより操作性を向上させることに よる対策を考える. 自動減速をおこなう方法は，レーザ 一スキャナを用いることにより実現させる．具体的な仕 組みは次項にて説明する. 自動減速をおこなうことのメ リットとしては，機械による検知のため，搭乗者の運転 能力に関わらず自動減速を行うことで事故の被害を減ら すもしくは誘発を防ぐことが出来ると考えられる．また， 人がおこなう動作のうち，障害物等を見つける認知の一 部と, 速度調整など速度に関する判断と操作の一部を機
械が補助することにより，搭乗者の負担が軽くなってハ ンドル操作がおこないやすくなり, 操作性が向上すると 考えられる. 一方, デメリットとしては，機械による勝 手な減速は搭乗者の走行の自由を奪うことにつながる可 能性があるなど，利便性を損なう可能性がある，自動減 速をおこなうことによる効果は明らかにされていないた め検証する必要がある。 また, 自動減速によって操作性 の向上が見込まれる場合, 日常生活でハンドル形電動車 いすを使用する際に自動減速をおこなうことが効果的な 状況を調べることも大切である.

\section{そこで本研究の目的は以下の二点とする.}

a. ハンドル形電動車いすを自動減速することによる操 作性・利便性の変化を検証する

b. 自動减速をおこなうことが効果的な状況を検証する 評価指標としては，操作性の変化を検証する指標とし て客観指標として衝突回数の計測, 主観指標としてヒア リングとアンケートを，利便性の変化を検証するために 客観指標として走行時間の計測, 主観指標としてヒアリ ング，アンケートを行う。また，効果的な状況は，アン ケート，ヒアリング結果をもとに検証する.

なお，自動減速の効果を検証する上で，レーザースキ ヤナによる検知範囲の設定は結果に大きく影響する. 自 動減速の効果を最大限計るために，今回は実験コースに 合った検知範囲を事前に検証し，設定する．最後の考察 では今回得られた知見より望ましい検知範囲についても 検証する. また，初めてハンドル形電動車いすを乗る人 にも効果があるか調べるため, ハンドル形電動車いすの 運転経験がない者を対象に実験をおこなう。

以上を検討することによりハンドル形電動車いすを自 動減速させることで利便性を損なわずに操作性を向上さ せることが出来るか検証し，特に効果的な状況を検証す ることで，事故防止や狭い空間での走行改善に役に立つ かを考えていく. なお，自動减速によって搭乗者が機械 に過度に依存しすぎることによる新たな問題も考えられ るが，今回は自動減速による効果の検証を目的とするた め，機械への依存は問題としないこととする.

\section{2. 本研究の位置づけ}

ハンドル形電動車いすは移動制約者の移動手段として は比較的新しい移動手段であるために既往研究自体限ら れている. 内容としてはハンドル形電動車いすの使用実 態に関する研究，利用する上で望ましい環境に関する研 究，事故に関する研究などがある.

実態把握の先行研究としては, 溝端・北川7) はハンド ル形電動車いす利用者と販売担当者を対象にアンケート 調査を行い，都市の規模の違いによる影響に注目しなが らハンドル形電動車いす利用者の特徵, 利用目的やその 
際の移動の距離などの普段の利用状況について調査を行 っている. その結果, 高齢者の利用がほとんどであるこ と，買い物の利用目的が一番多い事などを明らかにした。 また, 中島ら8)はハンドル形電動車い寸利用者へのヒア リング調查から, 施設で利用する際の問題として内部通 路が狭いなど物理的な制約が利用の妨げになっているこ とを指摘している，また，国土交通省は交通バリアフリ 一技術規格調査研究報告書9の中で，ハンドル形電動車 い寸を公共交通機関で使用寸る際の問題点について調査 をし，多くの既存の駅で物理的な制約により移動に困難 が生じる場合があると指摘している.これらの先行研究 により，ハンドル形電動車い寸利用者の多くが高齢者で あることや，公共機関や公共施設でハンドル形車い寸の 利用寸る際には, 物理的制約が多いため, 移動が困難と なる場合があることがわかっている.

事故に関する先行研究としては, 大賀ら ${ }^{10}$ は, ハンド ル型電動車い寸の単独の転倒や自動車との衝突を再現し, 転倒時の衝撃に関して検証している. ハンドル形電動車 い寸の危険・事故に関する先行研究の多くは, 事故の検 証を目的とするものや事故の影響を調査するものが中心 で，事故の発生を防ぐ対策を検討している研究は，森本

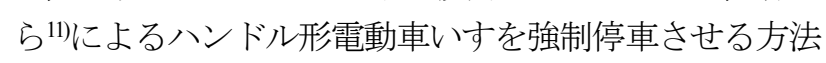
に関する研究以外ではほとんど行われていない.

また，ハンドル形電動車い寸を利用する上での望まし い環境に関して，石橋ら ${ }^{12}$ はハンドル形電動車い寸が安 全に走行するために必要とされる寸法について検討して いる. この知見は今後ハンドル形電動車い寸に対応した 整備をする際に重要な知見となるが，一方で，環境を改 善するには時間がかかるため, 現在の環境でも問題を改 善するための研究が必要となる.

先行研究では, 物理的制約により移動に困難が生じて いるなどの利用者の利用状況や，事故の状況などの現状 に関する研究はなされているが，現状の問題の対策につ いて言及している研究は少ない，また，少ないながら現 状の問題に対して言及している研究では, 利用環境や機 械側に注目した研究が多く, 利用者の運転技術に注目し た研究はまだない.よって搭乗者の運転技術に注目した 対策について研究する意義がある.

\section{3. 使用機材}

\section{(1) レ一ザースキャナについて}

本研究ではハンドル形電動車い寸の自動減速を実現す るためにレーザースキャナを用いる，今回使用したレー ザースキャナ（SE1L - H02LP 試作機，IDEC 社）の仕様 を表-1に，外観を図-1，ハンドル形電動車い寸への装着 した状態を図-2に示寸.

レーザースキャナはハンドル形電動車い寸の中心線上,

設置高さは，元々かごのあった床面からの高さ $540 \mathrm{~mm}$ に設置した．この高さは床面からレーザー発射位置まで の高さを示している.

レーザースキャナでは，レーザーを発射してから測定 対象にあたり, 反射したレーザーが再び戻ってくるまで の時間から対象までの距離を求める. これにより設定し たエリア内に障害物が入ったことを検知することができ る. 検知範囲は任意の図形として構成することができる. また，図-3に示すように 3 種類の対応が異なるエリア に分けて設定できる.

表-1 レーザースキャナの仕様

\begin{tabular}{|c|c|}
\hline 項目 & 仕様内容 \\
\hline 型式 & SE1L-H02LP試作機 \\
\hline 防護エリア & 最大 $3.5 \mathrm{~m}$ \\
\hline 警告エリア & 最大 $10 \mathrm{~m}$ \\
\hline 検出角度 & $190^{\circ}$ \\
\hline スキャン周期 & $30 \mathrm{~ms}$ \\
\hline 応答時間 & $\begin{array}{l}\text { off } 60 \mathrm{~ms} \sim 510 \mathrm{~ms} \\
\text { on } 210 \mathrm{~ms} \sim 510 \mathrm{~ms}\end{array}$ \\
\hline 外形寸法 & $90 \mathrm{~mm}(\mathrm{~L}), 90 \mathrm{~mm}(\mathrm{~W}), 95 \mathrm{~mm}(\mathrm{H})$ \\
\hline 重量 & 1.0kg以下 \\
\hline 光源波長 & $905 \mathrm{~nm}$ \\
\hline
\end{tabular}

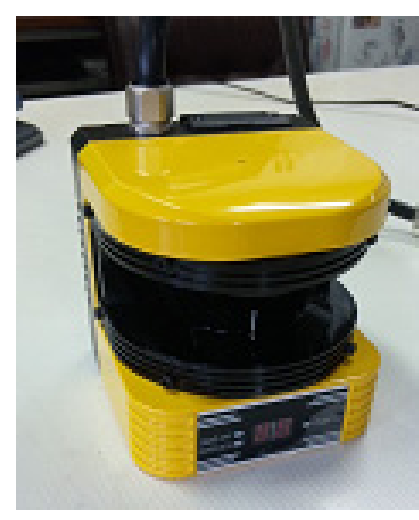

図-1 レーザースキャナの外観

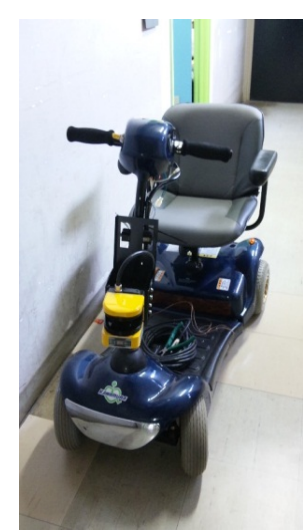

図-2 レーザースキャナ 付きハンドル形電 動車いすの外観

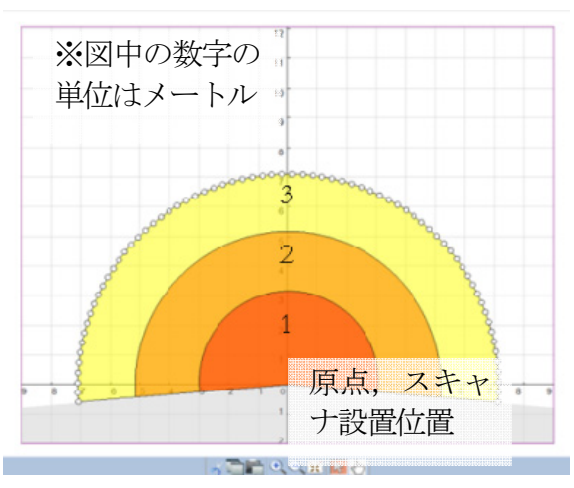

図-3 エリアの設定例 


\section{(2) 自動減速について}

ハンドル形電動車い寸の前方にレーザースキャナをつ けることにより，前方の障害物を検知させる．また，八 ンドルの向きとレーザースキャナの向きを連動させるこ とで，常に進行方向を検知できるようする．これにより， 走行中に設定したエリア内に入ってくる障害物を検知す ることができる．エリア範囲に入ってきた障害物をレー ザースキャナが検知すると，ハンドル形電動車い寸が自 動で減速する仕組みとなっている. エリア内に障害物が ない状態では, 通常のハンドル形電動車い寸と同様に最 高速度は $6 \mathrm{~km} / \mathrm{h}$ であるが，エリア内に障害物がある状態 では最高速度でも $2 \mathrm{~km} / \mathrm{h}$ までしか出ないようになる。こ の $2 \mathrm{~km} / \mathrm{h}$ は，事前に実験を行い，明確に原則を感じられ る速度を探り設定を行った。障害物を検知後, 速度は通 常の三分の一になる. なお今回使用したハンドル形電動 車いすでは，平均減速率は約 $2 \mathrm{~km} / \mathrm{h} / \mathrm{sec}$ であり， $6 \mathrm{~km} / \mathrm{h}$ で の走行時に障害物検知後，減速が完了寸るまでに約 $1 \mathrm{~m}$ 要する.

\section{(3) 検知エリアの設定について}

レーザースキャナを用いた自動减速方法はまだ開発途 中であり，検知エリアなどが確立されていない，実験を おこなう前にレーザースキャナのエリア設定について考 える必要がある，減速中のハンドル操作は操作ミスが考 えられるため，ハンドル操作を行う前に減速が完了寸る ような検知距離の設定をおこなう。その事前実験の結果， 車体幅を進行方向に $2.5 \mathrm{~m}$ 延長したエリアを設定した. このエリア設定を図-4に示した.

また，実験の際，自動減速の機能，意義について被験 者に説明を行った. 具体的には減速開始距離と減速完了 距離や検知エリアに関する情報を被験者に伝え，実際に ハンドル形電動車い寸に乗車し, 減速を経験させた.

\section{4. 実験}

\section{(1) 実験概要}

実験の概要を表-2 に示した. 実験コースは，ハンド ル操作をおこなう状況を想定したコースを 2 種類設定し た. その難易度は，日常生活でハンドル形電動車い寸を 利用寸る際に，操作性の向上が求められる状況を再現寸 る. 石橋ら ${ }^{13)}$ は，直行するそれぞれの通路幅が $100 \mathrm{~cm}$ 以 下となる場合, 通過が困難となる被験者が生じると示し ている．これをもとに， $100 \mathrm{~cm}$ の通路が直行する直角路 コースを設定した．概要図を図-5 に示した．特定建築 物の廊下や街路で，歩行者をよけながら通行する状況を 想定し，特定建築物などの廊下で望ましいとされている $180 \mathrm{~cm}$ の通路を設定した，さらに，通行する歩行者とし て障害物を設置した。この障害物は着衣した人の幅 60cm を設定した。 なお，壁から $20 \mathrm{~cm}$ 離して設置した. 障害物の設置数は, 歩行者と混在し, 回避をしなければ

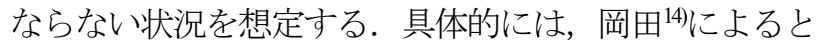
平日昼の地下街の歩行者密度は, 0.5 人 $/ \mathrm{m}^{2}$ であると述心 ているので，これをもとに設置数を算出した，なお，設 定した障害物コースの概要図を図-6に示した。なお, コースの壁，障害物はスタイロフォームを使用し作成し た. 高さは $2 \mathrm{~m}$ とした

評価指標としては操作性・利便性に関係寸ると考えら れる指標として，走行時間・衝突回数の計測による客観 指標とアンケート・ヒアリングによる主観指標をとる. 自動減速の有無により評価指標の変化を比較・分析する ことで目的を達成する．以下では自動減速させる場合を 「自動減速」，自動減速が無い場合を「現状」と呼ぶ.

\section{（2）実験手順}

実験前に被験者にはハンドル形電動車いすの運転習熟 のため事前走行を課した. ハンドル形電動車い寸の操作 方法を説明した後，10２0分走行練習をおこなう.

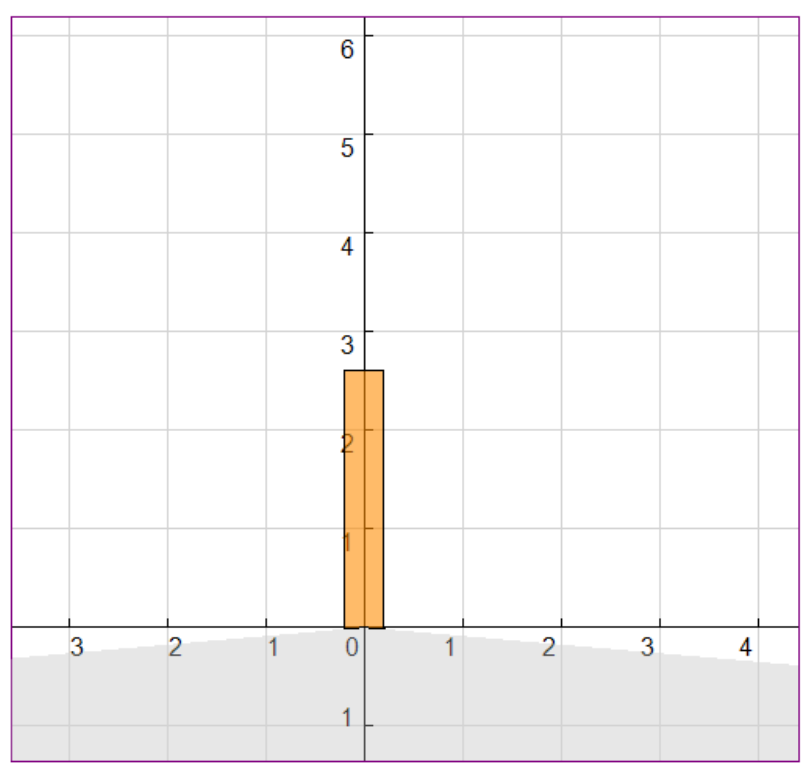

図-4＼cjkstart実験に使用したエリア設定

表-2 実験の概要

\begin{tabular}{|c|c|}
\hline 実験日 & $\begin{array}{l}2011 \text { 年 } 12 \text { 月 } 9 \text { 日 (午後) } \\
12 \text { 月 } 13 \text { 日 (午前・午後) } \\
12 \text { 月 } 16 \text { 日 (午後) }\end{array}$ \\
\hline 実験 & $9: 30-12: 00$ \\
\hline 時間帯 & $15: 00-17: 30$ \\
\hline $\begin{array}{l}\text { 実験 } \\
\text { 場所 }\end{array}$ & $\begin{array}{l}\text { 大阪大学フォトニクスセンターIDEC 株式 } \\
\text { 会社実験室内（室内） }\end{array}$ \\
\hline 被験者 & $\begin{array}{l}\text { 8名（65歳以上の男性 4名, 女性 4名） } \\
\text { ハンドル形電動車い寸の運転経験のない者 }\end{array}$ \\
\hline
\end{tabular}




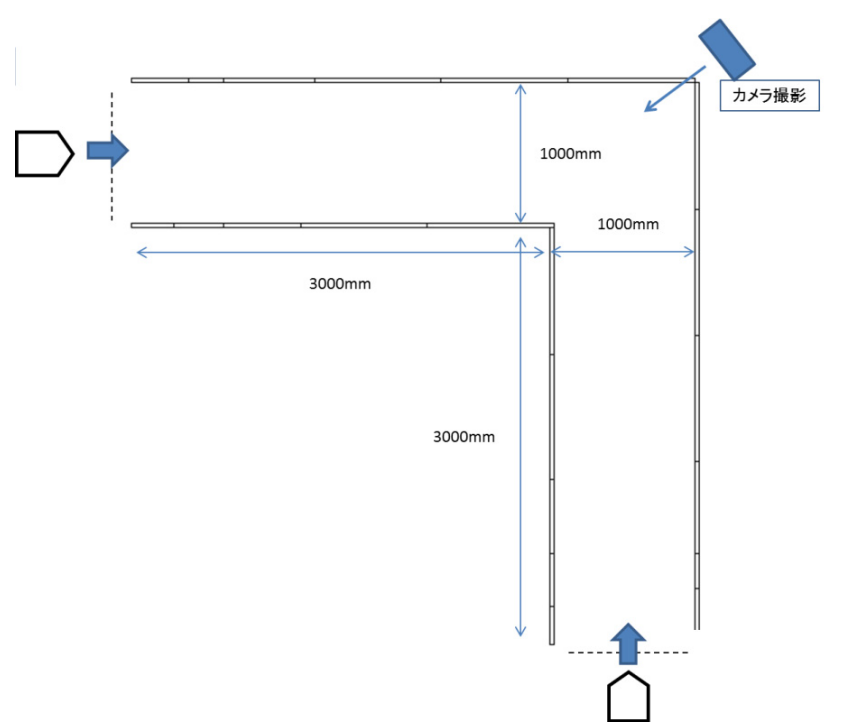

図-5＼cjkstart直角路コース概要図

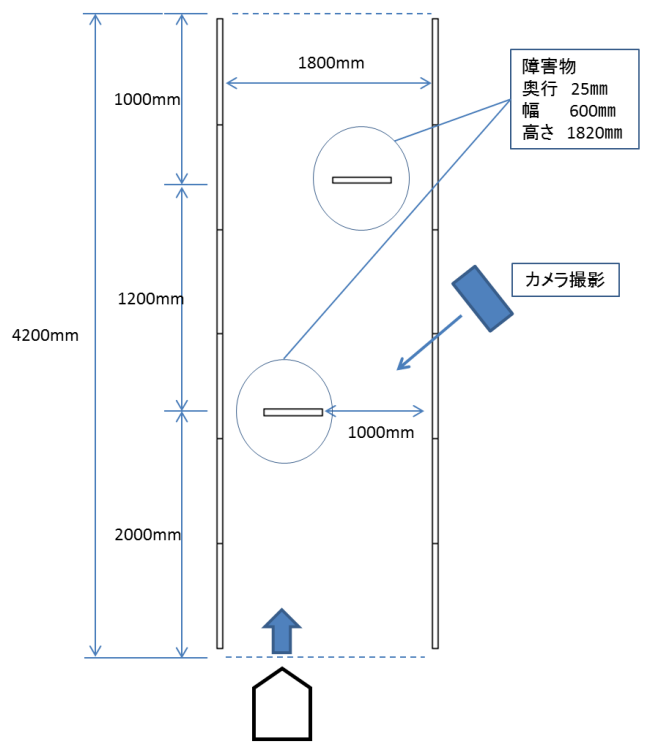

図-6 障害物コース概要図

事前走行により，ハンドル形電動車い寸の基本動作に ついて習熟してもらった. 実験手順を以下に示寸.

1. 被験者はスタート地点で待機し, 走行条件の確認 をおこなう。

2. 走行コース, 走行条件（自動減速の有無）の提示 順はランダムで変化させる.

3. スタートの合図とともに被験者はハンドル形電動 車い寸を発進させ，ゴール地点まで走行させる.

4. 走行中, 作業員の一人が被験者の後ろからついて いき被験者の走行時間とコースとの接触回数を記 録する．また，別の作業員は上から走行の模様を ビデオ撮影する.

5. 走行終了後, 被験者に各項目において 7 段階評価 のアンケートをしてもらう.
表-3 コース別平均走行時間と検定結果

\begin{tabular}{|c|r|r|r|c|}
\hline コース & \multicolumn{2}{|c|}{ 平均走行時間 (s) } & \multicolumn{1}{c|}{\begin{tabular}{l} 
意確率 \\
\cline { 2 - 3 } (中央値の検定)
\end{tabular}} & $\begin{array}{c}\text { 有意差 } \\
\text { (5\%水準) }\end{array}$ \\
\hline $\begin{array}{c}\text { 直角路 } \\
\text { (左折) }\end{array}$ & 13.43 & 12.38 & 0.026 & あり \\
\hline $\begin{array}{c}\text { 直角路 } \\
\text { (右折) }\end{array}$ & 16.67 & 14.43 & 0.161 & なし \\
\hline 障害物 & 14.36 & 14.67 & 0.449 & なし \\
\hline
\end{tabular}

※ 検定にはウィルコクソンの順位和検定を使用

以降 1〜5 を「現状」「自動減速」の場合それぞれで 走行してもらう．1 セット終了後，一対比較によるアン ケートを行う. 3 セット繰り返す. 3 セット終了後, 自 由回答によるヒアリングを行う。もう一方のコースでも 同様におこなう。なお， 1 回の実験で被験者 2 人の実験 をおこなう。但し，走行は交代で行い，実験中コース上 には被験者1名のみで実験を行った。

\section{(3) 検証方法}

自動減速による効果を検証するために，指標の計測を おこない，自動減速の有無の両者を比較し，効果を検証 する. 衝突回数の増減は操作性に関係し, 走行時間の増 減は利便性に影響すると考えられるため客観指標として 衝突回数・走行時間を採用する. また, 走行終了後にア ンケート・ヒアリングをおこなうことにより被験者の主 観による検証をおこなう。自動減速を行うことは被験者 の判断・操作に影響を与えると考えられる. そこでアン ケート項目にそれらの項目を作り検証をおこなう。

\section{5. 実験結果}

\section{（1） 走行時間の計測結果}

利便性の低下は，普段の走行時と比べて不便になる事 と考える事が出来る．走行時間が増加することは，搭乗 者がハンドル形電動車い寸を使用する際の利便性を損な うと考えられる，そこで自動減速を行うことにより走行 時間が増加しないか検証する．各コースにおける「現 状」と「自動减速」での走行時間の平均と，検定結果を 表-3に示す.

実験の結果，自動減速を行うことによる走行時間の増 加はみられなかった. よって, 今回の実験において走行 時間からの利便性を低下は確認できない。これより，今 回のコースでは自動減速を行うことにより搭乗者が不便 を被る可能性は少ないといえる.

\section{(2) 衝突回数の計測結果}

各コースにおける「現状」と「自動減速」での衝突回 数の平均と, 検定結果を表-4 に示す. なお, 自動減速 
表-4 コース別平均衝突回数と検定結果

\begin{tabular}{|c|r|r|r|c|}
\hline \multirow{2}{*}{ コース } & \multicolumn{2}{|c|}{ 平均衝突回数(回) } & \multicolumn{1}{c|}{\begin{tabular}{c} 
有意確率 \\
\cline { 2 - 5 }
\end{tabular} 現状 } & 自動減速意差 \\
(中央値の検定) & (5\%水準) \\
\hline $\begin{array}{c}\text { 直角路 } \\
\text { (左折) }\end{array}$ & 0.13 & 0.08 & 0.655 & なし \\
\hline $\begin{array}{c}\text { 直角路 } \\
\text { (右折) }\end{array}$ & 0.13 & 0.13 & 1.00 & なし \\
\hline 障害物 & 0.38 & 0.08 & 0.068 & なし \\
\hline
\end{tabular}

※ 検定にはウィルコクソンの順位和検定を利用

表-5 質問の回答項目と点数化

\begin{tabular}{|c|c|c|c|c|c|c|c|}
\hline & 3 & 2 & 1 & 0 & -1 & -2 & -3 \\
\hline a & 翡常に & 簡単 & $\begin{array}{l}\text { ごちら } \\
\text { かしい } \\
\text { えはは簡 } \\
\text { 単 }\end{array}$ & $\begin{array}{l}\text { どちら } \\
\text { でもな } \\
\text { い }\end{array}$ & $\begin{array}{l}\text { どちら } \\
\text { かんい } \\
\text { えはは難 } \\
\text { しい }\end{array}$ & 難しい & $\begin{array}{l}\text { 非常に } \\
\text { 難しい }\end{array}$ \\
\hline b & $\begin{array}{l}\text { 非常に } \\
\text { 判断し } \\
\text { やすい }\end{array}$ & $\begin{array}{l}\text { 判断し } \\
\text { やすい }\end{array}$ & $\begin{array}{l}\text { どちらか } \\
\text { ¿いえば } \\
\text { 判断しや } \\
\text { むい }\end{array}$ & $\begin{array}{l}\text { どちら } \\
\text { でもな } \\
\text { い }\end{array}$ & $\begin{array}{l}\text { ぞちらか } \\
\text { といえば } \\
\text { 判断しづ } \\
\text { らい }\end{array}$ & $\begin{array}{l}\text { 判断L } \\
\text { つららい }\end{array}$ & $\begin{array}{l}\text { 非常に } \\
\text { 判断し } \\
\text { づらい }\end{array}$ \\
\hline c & $\begin{array}{l}\text { ほとん } \\
\text { どイメ } \\
\text { ごシ通 } \\
\text { り }\end{array}$ & $\begin{array}{l}\text { 1x- } \\
\text { 溥通り }\end{array}$ & $\begin{array}{l}\text { どちらか } \\
\text { といえば } \\
\text { イメシジ } \\
\text { 通り }\end{array}$ & $\begin{array}{l}\text { どちら } \\
\text { でもな } \\
\text { い }\end{array}$ & 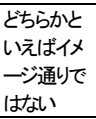 & $\begin{array}{l}\text { イメー } \\
\text { 涌り } \\
\text { ではな } \\
\text { い }\end{array}$ & $\begin{array}{l}\text { ほとんど } \\
\text { イメージ } \\
\text { 通りでは } \\
\text { ない }\end{array}$ \\
\hline$d$ & $\begin{array}{l}\text { 非常に } \\
\text { 便利 }\end{array}$ & 便利 & $\begin{array}{l}\text { どちら } \\
\text { かとい } \\
\text { えば便 } \\
\text { 利 }\end{array}$ & $\begin{array}{l}\text { どちら } \\
\text { でもな } \\
\text { い }\end{array}$ & $\begin{array}{l}\text { どちら } \\
\text { かとい } \\
\text { えば負 } \\
\text { 担 }\end{array}$ & 負担 & $\begin{array}{l}\text { 非常に } \\
\text { 負担 }\end{array}$ \\
\hline
\end{tabular}

表-6＼cjkstart難易度におけるアンケート結果

\begin{tabular}{|c|c|c|c|c|}
\hline コース & 項目 & 現状 & 自動減速 & 有意確率 \\
\hline \multirow{4}{*}{$\begin{array}{l}\text { 直角路 } \\
\text { コ一ス } \\
\text { (左折) }\end{array}$} & $\begin{array}{l}\text { コースの } \\
\text { 難易度 }\end{array}$ & 1.25 & 1.75 & $0.003^{* *}$ \\
\hline & \begin{tabular}{c|} 
曲がる \\
タイミングの判断 \\
\end{tabular} & 1.08 & 2.13 & $0.000^{* *}$ \\
\hline & ハンドル操作 & 1.00 & 1.46 & $0.040^{*}$ \\
\hline & $\begin{array}{l}\text { イメージ通りに } \\
\text { 走行できたか }\end{array}$ & 1.21 & 2.00 & $0.003^{* *}$ \\
\hline \multirow{4}{*}{$\begin{array}{l}\text { 直角路 } \\
\text { コ一ス } \\
\text { (右折) }\end{array}$} & $\begin{array}{c}\text { コースの } \\
\text { 難易度 }\end{array}$ & 1.08 & 1.74 & $0.002^{* *}$ \\
\hline & $\begin{array}{c}\text { 曲がる } \\
\text { タイミングの判断 } \\
\end{array}$ & 1.21 & 1.93 & $0.001^{* *}$ \\
\hline & ハンドル操作 & 1.04 & 1.48 & $0.007^{* *}$ \\
\hline & $\begin{array}{l}\text { イメージ通りに } \\
\text { 走行できたか }\end{array}$ & 1.30 & 1.51 & 0.185 \\
\hline \multirow[t]{4}{*}{$\begin{array}{l}\text { 障害物 } \\
\text { コース }\end{array}$} & $\begin{array}{c}\text { コースの } \\
\text { 難易度 }\end{array}$ & 0.67 & 1.42 & $0.016^{*}$ \\
\hline & $\begin{array}{c}\text { 曲がる } \\
\text { タイミングの判断 }\end{array}$ & 0.71 & 1.92 & $0.002^{* *}$ \\
\hline & ハンドル操作 & 0.42 & 1.38 & $0.001^{* *}$ \\
\hline & $\begin{array}{l}\text { イメージ通りに } \\
\text { 走行できたか }\end{array}$ & 0.79 & 1.67 & $0.002^{* *}$ \\
\hline
\end{tabular}

$* * 1 \%$ 有意 $* 5 \%$ 有意

※ 検定にはウィルコクソンの順位和検定を利用

を行うことにより衝突回数が減少するかを検証すること を目的とするため, 衝突箇所に関しては考慮しない.

実験の結果，自動減速を行うことによる衝突回数の減 少は全体としては見られなかったが，障害物コースで減 少傾向がみられる，減少傾向がみられる状況について次

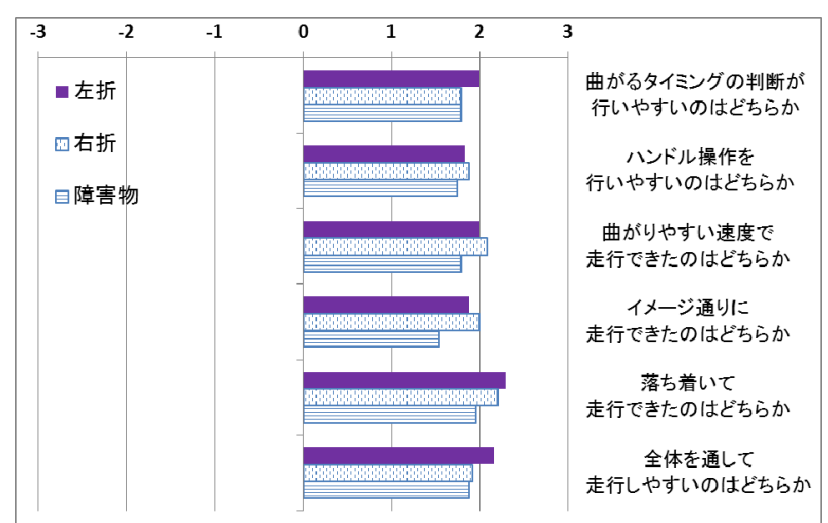

(+ : 自動减速の方がよい - : 現状の方が良い)

図-7 自動减速と現状の比較

章でもう少し詳しく分析する，検定結果で有意差がみら れなかった理由としては，元の「現状」での衝突回数が 少なく, サンプル数も少なかったため差が現れにくいと 考えられる.

\section{(3) アンケート結果}

アンケートは各走行終了時と，「現状」「自動減速」 両走行終了後の 2 種類おこなった. 前者は走行時の各種 難易度に関するアンケート，後者は自動減速の有無での 比較によるアンケートをおこなった.

走行時の各種難易度に関寸るアンケートでは，以下の a. 〜.の項目に関する質問を 7 段階評価で行った. 回答 項目を表-5 に記す．なお，アンケート結果を分析する にあたって，回答項目を評価ごとに点数化をおこない数 量データとして取り扱った。

a. 走行したコースの難易度はどうだったか

b. 曲がる際ハンドルを切るタイミングは判断しやすか ったか

c. ハンドル操作はおこないや寸かったか

d. イメージ通りに走行できたか

点数が高いほど各項目に対する評価が高いことを意味 する，評価方法は，質問項目ごとに全被験者の平均を集 計し，評価を行う．表-6にアンケート結果を示寸.

実験結果より，一つ以外全ての項目において 5\%有意 が確認でき，自動减速を行うことによって有意に評価が 高くなっていることがわかる，これより，自動減速を行 うことによって被験者自身は操作がおこないやすくなっ たと感じていることがわかる.

続いて自動减速の有無による比較でのアンケートでは, 「現状」「自動减速」両走行終了後に各項目について自 動減速の有無でどちらがよかったかアンケートをおこな った. アンケート結果と各項目について図-7 に示す. この結果より被験者は全ての項目において自動減速があ った方が評価が高いことがわかる. 
両アンケートの結果より，自動減速を行うことによっ て，曲がるタイミングが判断しやすくなる，落ち着いて 走行できるようになる, ハンドル操作がしやすくなると いうことがわかる. 被験者へのヒアリングからその理由 を考える. 落ち着いて走行できるようになった理由とし ては，障害物等の発見に遅れ，操作に遅れがあった際で も自動減速してくれることや障害物の近くでは速度が制 限されるため衝突しても大きな被害になりにくくなるこ とで安心感が生まれるため, 曲がるタイミングが判断し やすくなったりハンドル操作がおこないやすくなった理 由は，自動減速により速度調整がおこないやすくなった ため曲がるタイミングの判断やハンドル操作に集中でき るようになったため, と考えられる.

以上より，ハンドル形電動車いすを自動減速させるこ とにより今回のコースでは利便性を低下させることなく 操作性を向上させることができることがわかった.

\section{6. 分析}

\section{（1）各種条件別違いの検証}

条件の違いにより自動減速の効果に違いがあるか検証 する．検証方法は，各走行後におこなったアンケートに おいて自動減速によって各種項目の向上が条件によって 違いがでるかをカイ二乗検定をおこなうことによって検 証する. 検定の結果，コースの違い・走行回数の違いに よる自動減速の効果の違いはみられなかった。一方で 「現状」時に感じた走行難易度別によって自動減速の効 果に違いが表れた.「現状」走行時に感じた走行難易度 別にまとめたものを図-8に示す。これをみると「現 状」走行時に走行難易度を高いと感じた群ほど自動減速 を行うことによって操作性全般において向上する率が高
いことがわかる。

\section{(2) 分析のまとめ}

自動减速の効果は走行時に感じた難易度により, 効果 に違いが出てくることがわかった。その理由としては, 現状時に走行難易度を高く感じる人はハンドル操作や曲 がるタイミングの判断の難易度も高く感じる傾向にあり， そのような人たちには自動減速によって曲がるタイミン グの判断やハンドル操作の向上効果が期待できる.また 曲がるタイミングの判断やハンドル操作がおこないやす くなった結果, 走行難易度が簡単になったり, イメージ 通り走行しやすくなったりしたと考えられる. そのため, 現状時の走行難易度を高く感じる群では操作性全般が向 上したと考えられる。また，図-8より走行難易度を高 く感じる人は衝突回数も減少し, 客観指標からの向上も 見られる.

走行時に感じる難易度の差は，被験者によって異なる. 今回の実験では，運転免許の有無による差異は見られず， 被験者全員がハンドル形電動車いすの走行は初めてで練 習時間も同じであることを考えると，この違いは被験者 による習熟度の違いと考えることもできる．よって習熟 度の低い人ほど効果があると考えることもできる.

\section{7. 結論}

自動減速を行うことにより利便性を損なうことなく搭 乗者の主観的に操作性を向上させることがわかった。今 回客観指標から全体の向上は確認できなかったが，分析 の結果, 走行難易度を高く感じる群では客観指標の向上 も見られた。

さらに，アンケートやヒアリングの結果から直接的な

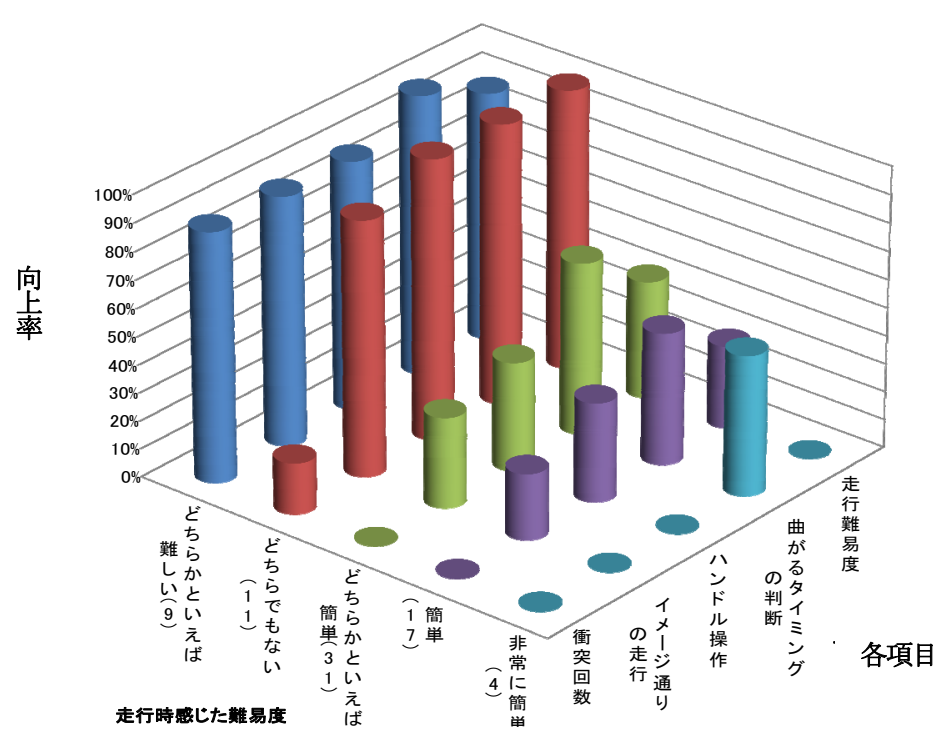

図-8「現状」走行時に感じた走行難易度別向上項目 
効果としては「速度調整がおこないやすくなる」「落ち 着いて走行できるようになる」。また，間接的な効果と して「曲がるタイミングの判断」「ハンドル操作がおこ ないや寸くなる」ことがわかった。

次にどのような状況で効果的であるかと検証した結果, 自動減速をおこなうことの効果は搭乗者が走行した際に 感じるコースの難易度によって差があることがわかり， 走行したコースの難易度を高く感じる人たちに自動减速 をおこなうと，操作性全般が向上するという結果となっ た. その理由として，走行難易度を高く感じている人は 曲がるタイミングの判断やハンドル操作の難易度も高く 感じていること, 曲がるタイミングの判断やハンドル操 作は難易度を高く感じている人ほど向上率が高いことが わかった。

最後に，今回は初心者のみを対象としたものであるた め, 経験者にも同様の効果があるのかを検証する必要が ある. また，今回の結果は実験コースのみの結果である ため, 日常空間でも同様の効果が得られるかも検証する 必要がある.その際に今回同様レーザースキャナを用い て自動減速をおこなう時には，事前実験を参考に考える と, 検知エリアは「ハンドル操作を行う前に速度減速が 終るよう調整する」「進行方向以外のものは検知しない よう調整する」などの配慮が必要と考えられる.

謝辞: 本研究は, 独立行政法人新エネルギー・産業技術 総合開発機構（NEDO）の委託事業「生活支援ロボット 実用化プロジェクト」において委託業務として行ってい るものです．本論文の執筆にあたり多大なご助言をいた だきました関係者の方々に深く感謝いたします。

\section{参考文献}

1) 内閣府共生社会政策統括官 : 平成 23 年版 高齢社会 白書, 2012.6 .

2) 電動車い寸安全普及協会: 出荷台数の推移, http://ww w.den-ankyo.org/society/transition.html，2012.（最終訪 問日 : 2013.7.7)
3）独立法人製品評価技術基盤機構 : 平成 19 年度ハンド ル形電動車いすの安全性調査結果についての報告書, http://www.nite.go.jp/jiko/press/080328/dendo_kuruma_is u.pdf, 2008.6. (最終訪問日：2013.7.7)

4) 国土交通省：交通バリアフリー技術規格調査研究報 告書, 2003.3 .

5) 国土交通省：公共交通機関の旅客施設に関する移動 等円滑化整備ガイドライン, pp.3-6, 2006.7.

6) 林邦宏 : 電動車いす, 電動三輪車, 四輪車の安全・ 快適技術, 国際交通安全学会誌, Vol.27, No.2, pp.107-114, 2002.10.

7) 溝端光雄, 北川博巳 : ハンドル型電動車いすの普及 と高齢者のモビリティに関する研究, 日本都市計画 論文集，Vol. 38，No.2，pp.41-51，2003.10.

8) 中島佐智子, 柏原士郎, 吉村英祐, 横田隆司, 飯田 匡 : ハンドル形電動車いすによる地域施設利用上の 問題点とその改善策, 日本建築学会学術講演梗概集, 2004 年, E-1 分冊, pp.223-224, 2004.7.

9）国土交通省：交通バリアフリー技術規格調査研究報告 書, http://www.mlit.go.jp/barrierfree/public-transport-bf/re search/handle/030910.pdf, 2003.3.

10) 大賀涼, 田久保宣晃, 木平真, 加藤憲史郎, 奥野 健：ハンドル型電動車いす交通事故に関する衝突実 験，自動車技術会論文集，Vol.40，No.3，pp.687-692， 2009.5.

11) 森本恭行, 猪井博登, 石橋達勇, 西岡基夫 : ハンド ル形電動車いすの単独事故発生防止における急停車 の搭乗者への負担調査, 土木計画学研究・講演集, Vol.42, CD-ROM, 2010.

12）石橋達勇, 西岡基夫, 猪井博登, 赤間寛子, 田中建 路：ハンドル形電動車いすの通路走行に関する基礎 的研究（その 1) 一公共施設内での利用実態と廊下等 での走行可能な寸法の検討一, 日本福祉のまちづく り学会 第 9 回全国大会概要集, 2006.

13) 石橋達勇, 西岡基夫, 猪井博登 : ハンドル形電動車 いすの通路走行に関する基礎的研究その 2-通路幅の 変化とハンドル操作性及び壁面への衝突状況一, 日 本福祉のまちづくり学会 第 11 回全国大会概要集, 2008.

14) 岡田光正 : 空間デザインの原点, 理工学社, pp.158, 1993.12 .

(2013. 2. 25 受付)

\section{IMPROVEMENT IN DRIVABILITY BY AUTOMATIC DECELERATION OF MOBILITY SCOOTER}

\section{Hiroto INOI, Shinya HASHIMOTO, Tatsuki KURIYAMA and Kazuya OKADA}

The number of accidents of mobility scooters is increasing. The mechanism of decelerating the speed of a mobility scooter is developed using the laser range finder. When the laser range finder notices barriers on direction of travel, deceleration is made automatically. The main purpose of this paper is to examine the improvement of maneuverability of mobility scooter by automatic deceleration. As the result automatic deceleration can be improved driving performance without worsening convenience. That shows the automatic deceleration can improve the safety and the operativity of a mobility scooter. And automatic deceleration can support driving of unaccustomed drivers. 